\title{
Remote Ischemia Preconditioning Attenuates Blood-Spinal Cord Barrier Breakdown in Rats Undergoing Spinal Cord Ischemia Reperfusion Injury: Associated with Activation and Upregulation of CB1 and CB2 Receptors
}

\author{
Na Jing Bo Fang Zhi-Lin Wang Hong Ma \\ Department of Anesthesiology, First Affiliated Hospital, China Medical University, Shenyang, Liaoning, \\ P. R. China
}

\section{Key Words}

Remote ischemic preconditioning • Blood-spinal cord barrier $\bullet$ CB1 receptor • CB2 receptor • Ischemia reperfusion injury

\begin{abstract}
Background/Aims: Remote ischemic preconditioning (RIPC) has protective effects on spinal cord ischemia reperfusion (I/R) injury, but the potential mechanisms remain unclear. In our study, the effects and underlying mechanisms of RIPC on blood-spinal cord barrier (BSCB) breakdown following I/R injury were investigated. Methods: animals underwent intraperitoneal administration with cannabinoid-1 (CB1) receptor antagonist AM251, cannabinoid-2 (CB2) receptor antagonist AM630 or vehicle 15 minutes before three 3-minute occlusionreperfusion cycles on the right femoral artery or a sham operation. 30 minutes after the preconditioning, aortic arch was exposed with or without 14-minute occlusion. Neurological function was assessed with Tarlov scoring system. The disruption of BSCB was assessed by measuring Evans Blue (EB) extravasation. The expression of tight junction protein occludin was determined by western blot analyses. The expression and localization of CB1 and CB2 receptors were assessed by western blot and immunofluorescence. Results: RIPC attenuated the motor dysfunction, BSCB disruption and downregulation of occludin after I/R injury, which were impaired by blocking CB1 and CB2 receptors. Moreover, RIPC upregulated the elevated perivascular expression of $C B 1$ and $C B 2$ receptors following I/R injury. Conclusions: These results indicated that RIPC, through activation and upregulation of CB1 and CB2 receptors, was involved in preserving the integrity of BSCB after spinal cord I/R injury.
\end{abstract}




\section{Cellular Physiology Cell Physiol Biochem 2017;43:2516-2524 \begin{tabular}{l|l|l} 
and Biochemistry Published online: October 31, 2017 & $\begin{array}{l}\text { (c) } 2017 \text { The Author(s). Published by S. Karger AG, Basel } \\
\text { www.karger.com/cpb }\end{array}$
\end{tabular} \\ Jing et al.: RIPC Attenuates BSCB Breakdown Following I/R Injury Mediated by CB1 and CB2 Receptors}

\section{Introduction}

Clinically, surgical repair of thoracoabdominal aneurysm can lead to temporary or permanent spinal cord I/R injury, whose incidence varies between 3\% and 20\% [1]. A major pathological change in spinal cord I/R injury is BSCB disruption, which further leads to neurological deficit. As shown in our previous studies, strategies protecting BSCB integrity can improve neurological function [2-6].

RIPC is a method in which short periods of non-lethal ischemia followed by reperfusion of tissue or organ protect remote tissue or organ to against a subsequent more severe I/R injury. Mounting evidence indicates that RIPC can induce spinal cord ischemia tolerance [7$11]$, but the exact mechanism is unclear yet. Remote ischemic postconditioning alleviating the disruption of blood-brain barrier (BBB) to induce cerebral ischemic tolerance has been reported $[12,13]$. Although BSCB and BBB are similar in both structure and function, the probability of RIPC preserving the integrity of BSCB following spinal cord I/R injury still needs to be confirmed.

A recent systematic review has suggested that receptor-mediated endocannabinoid system has been investigated as a latent neuroprotection target and it can alleviate ischemic injury [14]. Endocannabinoid system affording a protection to the BBB during I/R injury has been demonstrated $[15,16]$. Besides, a newly research suggested that CB2 receptor agonist might regulate the BSCB permeability [17].

Hence, our objectives in the present study were to investigate whether limb RIPC could initiate protective effects against BSCB disruption following spinal cord I/R injury, evaluate the cannabinoid receptors-dependent mechanism and the expression of CB1 and CB2 receptors in RIPC attenuating I/R induced BSCB breakdown.

\section{Materials and Methods}

\section{Animals}

Male Sprague-Dawley rats (280-320g, n=168) were obtained from the Laboratory Animal Center of China Medical University (Shenyang, China) and neurologically intact. The experimental protocols were approved by the Ethics Committee for Animal Experimentation of China Medical University and in accordance with the Guide for the Care and Use of Laboratory Animals (National Institutes of Health, Bethesda, Md).

\section{Experimental protocol}

All rats were randomly divided into six groups. G1 (Sham, n=36) group underwent the sham operations without limb RIPC and spinal cord I/R injury. G2 (Control, n=36) and G3 (RIPC, n=36) groups received the right femoral artery exposure or three 3-minute occlusion-reperfusion cycles 30 minutes before a 14-minute cross-clamping to the aortic arch followed by reperfusion. G4 (AM251, n=24), G5 (AM630, $\mathrm{n}=24$ ) and G6 (Vehicle, $\mathrm{n}=12$ ) groups received intraperitoneal administration with CB1 receptor antagonist AM251 (ENZO; 1mg/kg), CB2 receptor antagonist AM630 (ENZO; 1mg/kg) or equivalent volume of vehicle respectively 15 minutes before limb RIPC, followed by spinal cord I/R protocol.

\section{Limb RIPC and surgical procedures}

Limb RIPC was performed as previously described [10]. The right femoral artery was separated below the right groin ligament for later a 3-minute occlusion, followed by a 3-minute reperfusion. The RIPC consisted of 3 occlusion-reperfusion cycles. The spinal cord I/R injury was conducted by the previously described technique [18]. Briefly, rats were anesthetized by $4 \%$ sodium pentobarbital ( $50 \mathrm{mg} / \mathrm{kg}$, intraperitoneally). Expose and cross-clamp the aortic arch between the left common carotid artery and the left subclavian artery under direct visualization. Monitor and maintain the rectal temperature at $37 \pm 0.5^{\circ} \mathrm{C}$ using a heated operating table. Catheters were inserted into the tail artery and the left carotid artery to measure distal and proximal blood pressure respectively. The ischemia was confirmed by a $90 \%$ reduction of blood flow measured at the tail artery with the aid of a laser Doppler blood flow monitor (Moor Instruments, Axminster, 


\section{Cellular Physiology Cell Physiol Biochem 2017;43:2516-2524 \begin{tabular}{l|l|l} 
DOI: 10.1159/000484460 & Ond Biochemistry Published online: October 31, 2017 & $\begin{array}{l}\text { 2 2017 The Author(s). Published by S. Karger AG, Basel } \\
\text { www.karger.com/cpb }\end{array}$
\end{tabular} \\ Jing et al.: RIPC Attenuates BSCB Breakdown Following I/R Injury Mediated by CB1 and CB2 Receptors}

Devon, UK). After a 14-minute ischemia, the occlusion was relieved. Sham operation rats received the same protocol without clamping the aortic arch.

\section{Neurological assessment}

Neurological function are assessed by investigators blinded to the experimental processes at $4 \mathrm{~h}$ and $24 \mathrm{~h}$ after reperfusion, using a Tarlov scoring system [19]: 0 , no lower extremity function; 1 , appreciable lower extremity function, only feeble antigravity movement; 2 , moderate movement of lower extremity with good antigravity strength, but unable to stand; 3, capacity to stand and hop, but not normally; 4 , normal motor function.

\section{BSCB leakage evaluation}

Measurement of Evans Blue (EB) extravasation was used to evaluate the permeability of BSCB. At $4 \mathrm{~h}$ and $24 \mathrm{~h}$ after reperfusion, the amount and flsorescence of EB were used to examine BSCB integrity quantitativly and qualitativly. Briefly, EB dye (20 g/L, $10 \mathrm{ml} / \mathrm{kg}$; Sigma) was injected into the caudal vein slowly. After $1 \mathrm{~h}$, the spinal cord tissue was weighed and soaked in methanamide for $24 \mathrm{~h}\left(60^{\circ} \mathrm{C}\right)$, then centrifuged. A microplate reader (BioTek, Winooski, USA) was used for detecting the absorption of the supernatant at 632 $\mathrm{nm}$. The EB content was reported as micrograms per gram of spinal cord tissue with standardized curve. In addition, after fixing the spinal cord tissue with $4 \%$ paraformaldehyde and sectioning $(10 \mu \mathrm{m})$, the EB flsorescence was visualized with a BX-60 (Olympus, Melville, NY) flsorescence microscope (green zone).

\section{Western Blot}

BSCB tight junction protein occludin, CB1 and CB2 receptors in spinal cord tissue were analyzed by sodium dodecyl sulfate polyacrylamide gel electrophoresis. The antibodies were used as follows: rabbit polyclonal anti-Occludin (1:500, Abcam 31721), rabbit polyclonal anti-cannabinoid receptor I (1:500, Abcam 23703), rabbit polyclonal anti-cannabinoid receptor II (1:500, Abcam 3561) and horseradish peroxidaseconjugated secondary antibodies (Bioss, Beijing, China).

The specificity of a number of cannabinoid receptor antibodies has been indicated to be an issue [20, $21]$, but the antibodies used in our investigation (as shown above) were not included in those studies. In addition, several published articles have validated the specificity of the two commercial cannabinoid receptor antibodies [22-26].

\section{Double immunofluorescence staining}

To identify the perivascular location of CB1 and CB2 receptors, double immunofluorescence labeling for CB1 and CB2 receptors with vascular endothelial cells marker CD31 was performed. The sections were incubated with primary antibodies: mouse monoclonal anti-CD31 [P2B1] (1:100, Abcam 24590) together with rabbit polyclonal anti-cannabinoid receptor I (1:50, Abcam 23703) or rabbit polyclonal anti-cannabinoid receptor II (1:500, Abcam 3561), and followed by corresponding secondary antibodies: Alexa 594-conjugated donkey anti-mouse IgG (1:200, Abcam 150108) and Alexa 488-conjugated donkey anti-rabbit IgG (1:200, Abcam 150073). The Leica TCS SP2 (Leica Microsystems, Buffalo Grove, IL, USA) laser scanning spectral confocal microscope was used to analyze and image the sections.

\section{Statistical analysis}

All data were presented as means \pm SEM and analyzed with SPSS 17.0 statistical software. Oneway ANOVA with Newman-Keuls post-hoc analysis was applied to assess the data. Values of $\mathrm{P}<0.05$ was considered to be statistically significant.

\section{Results}

\section{Neurological assessment}

The individual neurological scores of the six groups at $4 \mathrm{~h}$ and $24 \mathrm{~h}$ after reperfusion are shown in Fig. 1A, B. There was no neurological change in the sham group, and all of the other groups of rats showed motor deficit in varying degrees. RIPC enhanced the recovery of motor function (RIPC group versus control group; $\mathrm{P}<0.05$, at $4 \mathrm{~h}$ and $24 \mathrm{~h}$ respectively). 
At $4 \mathrm{~h}$ after reperfusion, compared with RIPC group, the neurological outcome in the AM251 group was statistically worse $(\mathrm{P}<0.05)$. The scores in RIPC, AM630, and vehicle groups did not show significant difference. Whereas, at $24 \mathrm{~h}$ after reperfusion, both AM251 and AM630 pretreatment statistically abolished the neuroprotective effect of RIPC (AM251 and AM630 groups versus RIPC group; $\mathrm{P}<0.05$, respectively).

\section{RIPC attenuated BSCB breakdown following I/R injury, impaired by blocking CB1 and CB2 receptors}

EB extravasation visualized as red under the fluorescent microscope (Fig. 2A-L) and quantitative analysis of EB content in spinal cord tissue (Fig. 2M) were commonly used for evaluating the permeability of the BSCB. I/R injury caused a marked increase of EB extravasation regarded as sham group $(\mathrm{P}<0.05)$. RIPC reduced the levels of extravasation after I/R injury at both $4 \mathrm{~h}$ and $24 \mathrm{~h}(\mathrm{P}<0.05)$, indicating that RIPC preserved BSCB integrity.

Fig. 1. Assessment of neurological motor function with Tarlov score. (A) 4 $h$ after I/R injury. (B) $24 \mathrm{~h}$ after I/R injury.
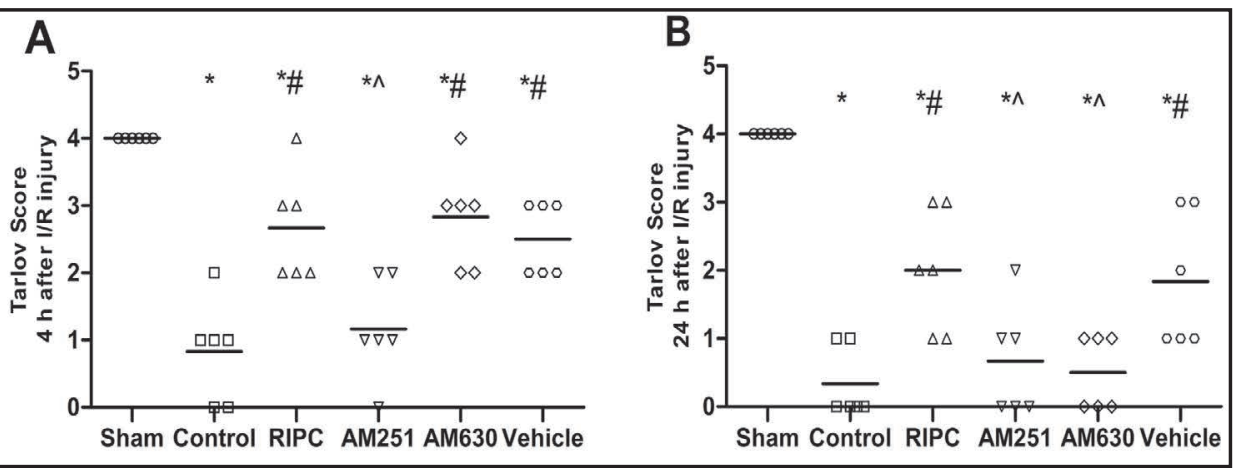
Each symbol represents score for one rat ( $\mathrm{n}=6$ per group at each time point, bar $=$ median). ${ }^{*} \mathrm{P}<0.05$ versus sham group. \# $\mathrm{P}<0.05$ versus control group; ${ }^{\wedge} \mathrm{P}<0.05$ versus $\mathrm{RIPC}$ group.

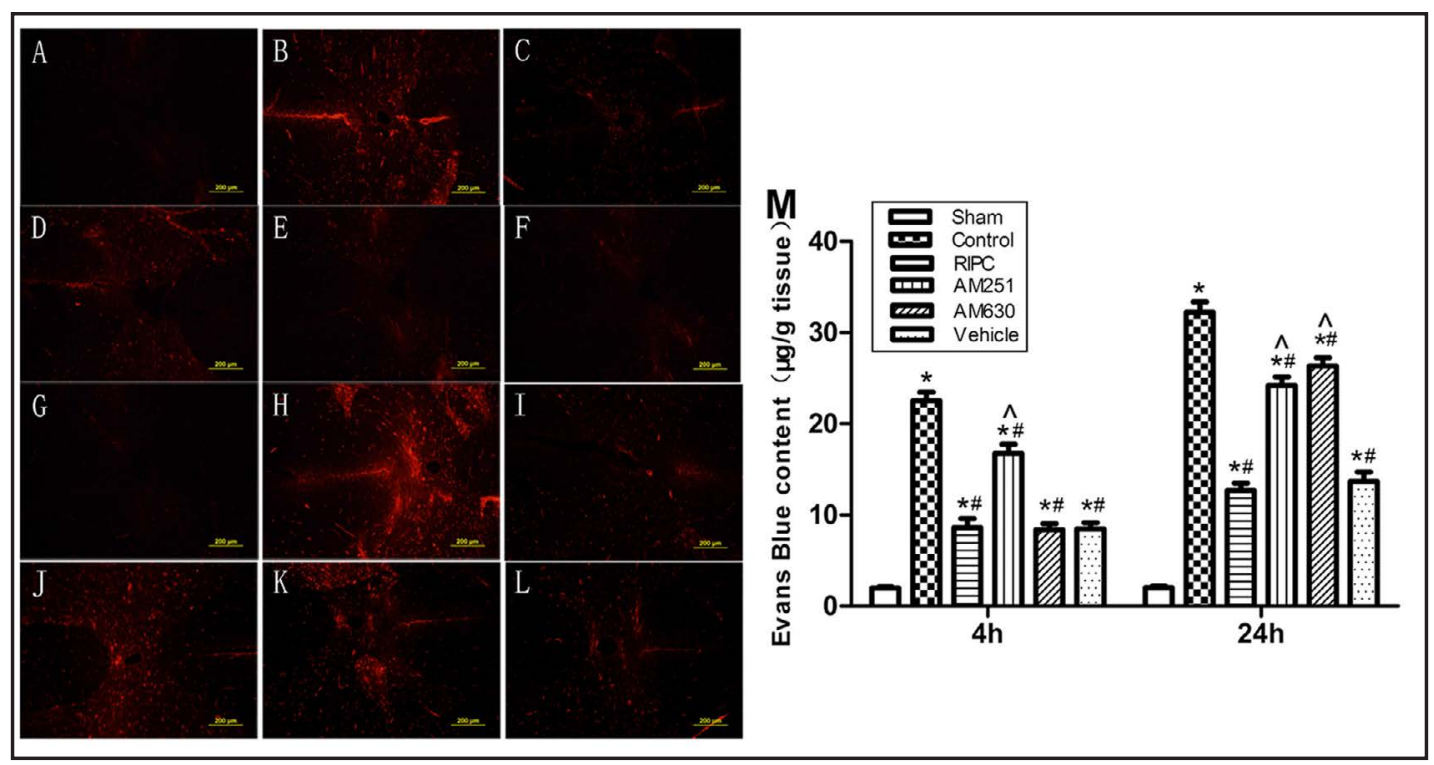

Fig. 2. Evaluation of BSCB permeability following spinal cord $I / R$ injury. (A-L) Red fluorescence of EB extravasation. At $4 \mathrm{~h}$ and $24 \mathrm{~h}$ after injury respectively, A and G: Sham group; B and H: Control group; C and I: RIPC group; D and J: AM251 group; E and K: AM630 group; F and L: Vehicle group. Scale bars are $200 \mu \mathrm{m}$. (M) Amount of EB in the spinal cord tissue $(\mu \mathrm{g} / \mathrm{g})$ are presented as mean \pm SEM $(\mathrm{n}=6$ per group at each time point). ${ }^{*} \mathrm{P}<0.05$ versus sham group; $\# \mathrm{P}<0.05$ versus control group; ${ }^{\wedge} \mathrm{P}<0.05$ versus $\mathrm{RIPC}$ group. 
Additionally, CB1 receptor antagonist AM251 pretreatment partially reversed the effect of RIPC on reducing EB extravasation following I/R injury at both $4 \mathrm{~h}$ and $24 \mathrm{~h}$ (AM251 group versus control and RIPC groups; $\mathrm{P}<0.05$, at $4 \mathrm{~h}$ and $24 \mathrm{~h}$ respectively); while CB2 receptor antagonist AM630 impaired the protective effect of RIPC only at $24 \mathrm{~h}$ after injury (AM630 group versus control and RIPC groups; $\mathrm{P}<0.05$ ).

RIPC suppressed downregulation of occludin after I/R injury, impaired by blocking CB1 and $C B 2$ receptors

Western blot analysis indicated that I/R injury induced decreased occludin expression, and RIPC depressed the downregulation of occludin $(\mathrm{P}<0.05)$. As shown in Fig. 3A, at $4 \mathrm{~h}$ after I/R injury, the level of occludin in AM251 group was remarkably less than that of RIPC group ( $\mathrm{P}<0.05)$; while AM630 group had similar occludin expression to RIPC group. At 24 $\mathrm{h}$ after injury (Fig. 3B), compared to RIPC group, occludin level in both AM251 and AM630 groups decreased obviously $(\mathrm{P}<0.05)$.

Fig. 3. Representative western blot and quantitative protein analysis of occludin in the spinal cord tissue at (A) $4 \mathrm{~h}$ and (B) $24 \mathrm{~h}$ after injury. All data are presented as mean $\pm \operatorname{SEM}(n=6$ per group at each time point). ${ }^{*} \mathrm{P}<0.05$ versus

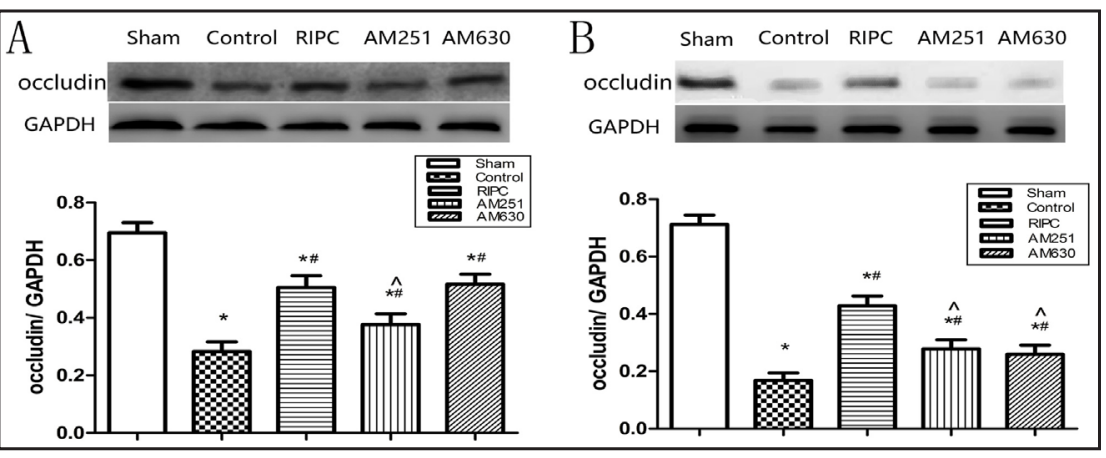
sham group; $\# \mathrm{P}<0.05$ versus control group; ${ }^{\wedge} \mathrm{P}<0.05$ versus $\mathrm{RIPC}$ group.

Fig. 4. RIPC upregulated the endogenous increase of CB1 and CB2 receptors following $I / R$ injury. (A, B) Representative Western blot and quantitative protein analysis of CB1 and CB2 receptors in the spinal cord tissue at $4 \mathrm{~h}$ and $24 \mathrm{~h}$ after injury. Immunofluorescence photomicrographs of (C) CB1 receptor colocalized with vascular endothelial cell (CD31) at $4 \mathrm{~h}$ and (D) CB2 receptor colocalized with vascular endothelial cell (CD31) at $24 \mathrm{~h}$ after injury. All

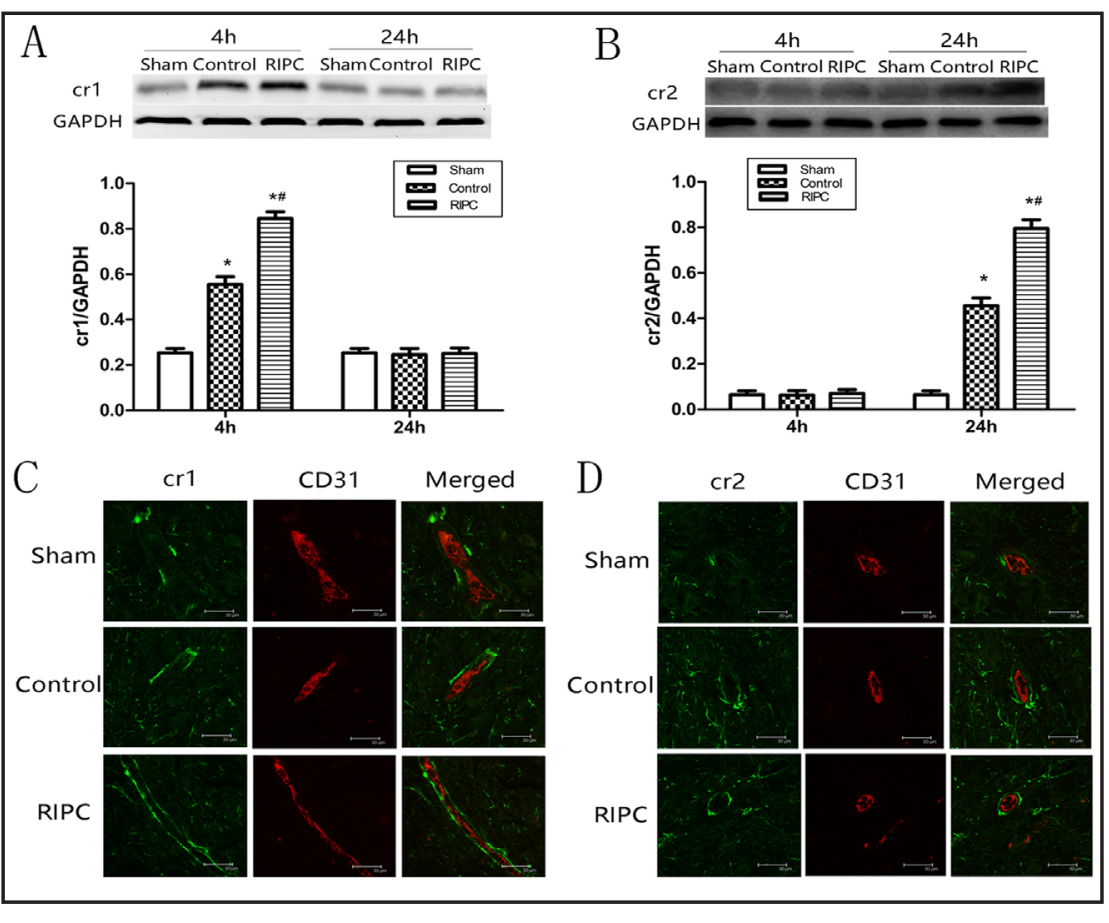
data are presented as mean \pm SEM ( $n=6$ per group at each time point). ${ }^{*} \mathrm{P}<0.05$ versus sham group; $\# \mathrm{P}<0.05$ versus control group. 


\section{Cellular Physiology Cell Physiol Biochem 2017;43:2516-2524 \\ \begin{tabular}{ll|l} 
and Biochemistry & $\begin{array}{l}\text { DOI: } 10.1159 / 000484460 \\
\text { Published online: October 31, } 2017\end{array}$ & $\begin{array}{l}\text { C } 2017 \text { The Author(s). Published by S. Karger AG, Basel } \\
\text { www.karger.com/cpb }\end{array}$ \\
\hline
\end{tabular} \\ Jing et al.: RIPC Attenuates BSCB Breakdown Following I/R Injury Mediated by CB1 and CB2 Receptors}

RIPC upregulated the endogenous increase of CB1 and CB2 receptors exhibiting a perivascular location following I/R injury

Western blot analysis showed a acute and rapid increase of CB1 receptor (cr1) at $4 \mathrm{~h}$ after injury which came back to sham level at $24 \mathrm{~h}(\mathrm{P}<0.05$; Fig. $4 \mathrm{~A})$, while $\mathrm{CB} 2$ receptor (cr2) augmented at $24 \mathrm{~h}$ after injury ( $<<0.05$; Fig. 4B). RIPC enhanced upregulation of both $\mathrm{CB} 1$ and CB2 receptors after I/R injury $(\mathrm{P}<0.05)$. Further, at the time point when CB1 or CB2 receptor expressing significantly more, double immunofluorescence labeling for $\mathrm{CB} 1$ and CB2 receptors with vascular endothelial cell marker CD31 revealed as shown in Fig. 4C, D, there was discontinuous arrangement of CB1 receptor-positive protein along the vasculature of spinal cord in sham group, while almost no CB2 receptor-positive protein; CB1 and CB2 receptors endogenously increased at different time points after I/R injury, which could be upregulated by RIPC.

\section{Discussion}

Our study investigated the beneficial effect of limb RIPC in preserving the integrity of BSCB following I/R injury. Findings from the present study showed that RIPC attenuated BSCB disruption and downregulation of occludin, preserved the extremity motor function following spinal cord I/R injury, which were associated with the activation of CB1 and CB2 receptors. Moreover, we found that RIPC could upregulate the endogenous increase of CB1 and $\mathrm{CB} 2$ receptors distributing along the vasculature of spinal cord after I/R injury.

BSCB plays a vital role in maintaining homeostasis of the spinal cord. Both the function and structure of BSCB are disrupted in case of I/R injury, further leading to neurological deficit. Similar to BBB, endothelial cells between capillaries, tight junction (TJ), basement membrane, astrocytic end feet processes, and pericytes are the basic components of BSCB [27]. Occludin, one of the tight junction proteins, has been reported to be a sensitive indicator of the functional state of the BBB [28]. Correspondence with previous study in our laboratory [2], the current research showed that occludin decreased after I/R injury, concurrent with a increase of BSCB permeability and motor dysfunction. RIPC significantly improved neurological assessment scores, along with BSCB leakage and occludin downregulation, indicating that RIPC induced spinal cord ischemia tolerance by preserving BSCB integrity.

Humoral communication, systemic modification of circulating immune cells, neuronal stimulation, and activation of hypoxia inducible genes can be the signaling pathway of RIPC [29]. Endocannabinoid as one of the humoral pathway has been reported to involve in the RIPC protective effect on spinal cord I/R injury [10]. Furthermore, exogenous activation of CB2 receptor regulating the BSCB permeability has been documented [17]. Our results suggested that blockade of CB1 receptor impaired the benificial effect of RIPC on motor function, BSCB permeability and tight junction protein occludin at both $4 \mathrm{~h}$ and $24 \mathrm{~h}$ following I/R injury; while only at the later time point, we observed blockade of CB2 receptor impaired the protective effect of RIPC. This proposed a potential mechanism that RIPC attenuate BSCB breakdown following spinal cord I/R injury mediated by the activation of CB1 and CB2 receptors, confirming and extending the previous studies. Also, it indicated the various expression of $\mathrm{CB} 1$ and $\mathrm{CB} 2$ receptors at different time points.

The altered components of endocannabinoid system in ischemic injury indicate an important role of endocannabinoid system in the endogenous response to ischemic injury. Endocannabinoids are released rapidly following either brain or spinal cord injury [30, 31]. The CB1 and CB2 receptors expression in the brain are elevated after cerebral ischemia. So far, evidence has accumulated that the expression of CB1 receptor increases after ischemia and reach to peak within $2 \mathrm{~h}$ to $6 \mathrm{~h}$ postischemia, comparing with the delayed increase of CB2 receptor expression after $24 \mathrm{~h}$ postischemia [32-37]. The difference between the time course of these two receptors expression is, at least partially, due to changes in the type of cells expressing them. A study on spinal cord lesion suggested that CB1 receptor, which can be induced by reactive astrocytes, expressed constitutively in neurons and oligodendrocytes, 


\section{Cellular Physiology Cell Physiol Biochem 2017;43:2516-2524 \\ and Biochemistry \begin{tabular}{l|l} 
Published online: October 31, 2017 & $\begin{array}{l}\text { C } 2017 \text { The Author(s). Published by S. Karger AG, Basel } \\
\text { www.karger.com/cpb }\end{array}$ \\
\hline Jing et al.: RIPC Attenuates BSCB Breakdown Following I/R Injury Mediated by CB1 and
\end{tabular} CB2 Receptors}

while CB2 receptor strongly expressed following injury, mostly in astrocytes and immune infiltrates [38]. In the current work, consistent with most recent studies, western blotting and immunofluorescence staining showed that there was a basal expression of CB1 receptor in sham group, and the expression increased at $4 \mathrm{~h}$ following injury which returned to sham level at $24 \mathrm{~h}$; while, there was almost no CB2 receptor expression in sham group and control group at $4 \mathrm{~h}$ after injury, but it strongly expressed at $24 \mathrm{~h}$ after injury. Besides, we found RIPC could upregulate the endogenous increase of CB1 and CB2 receptors, extending the previous study that RIPC induced an increase of endocannabinoids level [10]. In our study, the outcome that CB1 receptor antagonist AM251 pretreatment could still play a role in impairing the protective effect of RIPC at $24 \mathrm{~h}$ after injury, maybe due to the blockade of the binding of basal expressed CB1 receptor and the increased endocannabinoids induced by I/R injury or RIPC.

In the present study, we focused on the effect of CB1 and CB2 receptors on RIPC preserving BSCB integrity, so we only colocalized CB1 and CB2 receptors with vascular endothelial cells to identify the perivascular exhibition of CB1 and CB2 receptors, instead of locating the specific CB1/CB2 receptor-positive cell types. Moreover, we only investigated the effect of RIPC at $4 \mathrm{~h}$ and $24 \mathrm{~h}$ after reperfusion, which is a relatively short period of time. A longer observation duration will be necessary. Meanwhile, the exact mechanisms of CB1 and CB2 receptors activation in RIPC attenuating BSCB disruption after I/R injury were not clarified by this study. We speculated that the possible mechanisms are gliocytes activation and inflammatory response modification. All of these need to be elucidated in further studies.

Overall, our results provide compelling evidence that limb RIPC attenuate BSCB breakdown following spinal cord I/R injury. This protective effect is associated with activation of CB1 and CB2 receptors. In addition, RIPC can upregulate the elevated perivascular expression of CB1 and CB2 receptors after I/R injury.

\section{Acknowledgements}

This study was supported by a grant from the Natural Science Foundation of China (No. 81401000).

\section{Disclosure Statement}

The authors declare no conflict of interest.

\section{References}

1 Murana G, Castrovinci S, Kloppenburg G, Yousif A, Kelder H, Schepens M, de Maat G, Sonker U, Morshuis W, Heijmen R: Open thoracoabdominal aortic aneurysm repair in the modern era: results from a 20-year single-centre experience. Eur J Cardiothorac Surg 2015;49:1374-1381.

-2 Fang B, Wang H, Sun XJ, Li XQ, Ai CY, Tan WF, White PF, Ma H: Intrathecal transplantation of bone marrow stromal cells attenuates blood spinal cord barrier disruption induced by spinal cord ischemia reperfusion injury in rabbits. J Vasc Surg 2013;8:1043-1052.

-3 Fang B, Li XM, Sun XJ, Bao NR, Ren XY, Lv HW, Ma H: Ischemic Preconditioning Protects against Spinal Cord Ischemia-Reperfusion Injury in Rabbits by Attenuating Blood Spinal Cord Barrier Disruption. Int J Mol Sci 2013;14:10343-10354.

4 Li XQ Wang J, Fang B, Tan WF, Ma H: Intrathecal antagonism of microglial TLR 4 reduces inflammatory damage to blood-spinal cord barrier following ischemia/reperfusion injury in rats. Mol Brain 2014;7:28 


\section{Cellular Physiology Cell Physiol Biochem 2017;43:2516-2524 \begin{tabular}{l|l|l}
\hline DOI: 10.1159/000484460 & (C) 2017 The Author(s). Published by S. Karger AG, Basel
\end{tabular} and BIOChemistry Published online: October 31, 2017 www.karger.com/cpb \\ Jing et al.: RIPC Attenuates BSCB Breakdown Following I/R Injury Mediated by CB1 and CB2 Receptors}

5 Li XQ Cao XZ, Wang J, Fang B, Tan WF, Ma H: Sevoflurane preconditioning ameliorates neuronal deficits by inhibiting microglial MMP-9 expression after spinal cord ischemia/reperfusion in rats. Mol Brain 2014;7:69.

6 Fang B, Li XQ, Bi B, Tan WF, Liu G, Zhang Y, Ma H: Dexmedetomidine Attenuates Blood-Spinal Cord Barrier Disruption Induced by Spinal Cord Ischemia Reperfusion Injury in Rats. Cell Physiol Biochem 2015;36:373383

7 Sapmaz A, Ulus AT, Turan NN, Kaymaz FF, Yazıcıŏlu H, Ersöz S, Simsek E, Köksoy C: Which type of conditioning method protects the spinal cord from the ischemia-reperfusion injury in 24 hours? Vascular 2015;23:614-621.

-8 Haapanen H, Herajärvi J, Arvola O, Anttila T, Starck T, Kallio M, Anttila V, Tuominen H, Kiviluoma K, Juvonen T: Remote ischemic preconditioning protects the spinal cord against ischemic insult: an experimental study in a porcine model. J Thorac Cardiovasc Surg 2016;151:777-785.

-9 Selimoglu O, Ugurlucan M, Basaran M, Gungor F, Banach M, Cucu O, Ong LL, Gasparyan AY, Mikhailidis D, Ogus TN: Efficacy of remote ischaemic preconditioning for spinal cord protection against ischaemic injury: association with heat shock protein expression. Folia Neuropathol 2008;46:204-212.

10 Su B, Dong H, Ma R, Zhang X, Ding Q, Xiong L: Cannabinoid 1 receptor mediation of spinal cord ischemic tolerance induced by limb remote ischemia preconditioning in rats. J Thorac Cardiovasc Surg 2009;138:1409-1416.

11 Dong HL, Zhang Y, Su BX, Zhu ZH, Gu QH, Sang HF, Xiong L: Limb remote ischemic preconditioning protects the spinal cord from ischemia-reperfusion injury: a newly identified nonneuronal but reactive oxygrn species-dependent pathway. Anesthesiology 2010;112:881-891.

12 Li S, Hu X, Zhang M, Zhou F, Lin N, Xia Q, Zhou Y, Qi W, Zong Y, Yang H, Wang T: Remote ischemic postconditioning improves neurological function by AQP4 down-regulation in astrocytes. Behav Brain Res 2015;289:1-8.

13 Ren C, Gao M, Dornbos D 3rd, Ding Y, Zeng X, Luo Y, Ji X: Remote ischemic post-conditioning reduced brain damage in experimental ischemia/reperfusion injury. Neurol Res 2011;33:514-519.

14 England TJ, Hind WH, Rasid NA, O'Sullivan SE: Cannabinoids in experimental stroke: a systematic review and meta-analysis. J Cereb Blood Flow Metab 2015;35:348-358.

15 Hind WH, Tufarelli C, Neophytou M, Anderson SI, England TJ, O’Sullivan SE: Endocannabinoids modulate human blood-brain barrier permeability in vitro. Br J Pharmacol 2015;172:3015-3027.

16 Zhang M, Adler MW, Abood ME, Ganea D, Jallo J, Tuma RF: CB2 receptor activation attenuates microcirculatory dysfunction during cerebral ischemic/reperfusion injury. Microvasc Res 2009;78:86-94.

17 Yang MC, Zhang HZ, Wang Z, You FL, Wang YF: The molecular mechanism and effect of cannabinoid-2 receptor agonist on the blood-spinal cord barrier permeability induced by ischemia-reperfusion injury. Brain Res 2016;1636:81-92.

18 Awad H, Ankeny DP, Guan Z, Wei P, McTigue DM, Popovich PG: A mouse model of ischemic spinal cord injury with delayed paralysis caused by aortic cross-clamping. Anesthesiology 2010;113:880-891.

19 Huang CY, Chen YL, Li AH, Lu JC, Wang HL: Minocycline, a microglial inhibitor, blocks spinal CCL2-induced heat hyperalgesia and augmentation of glutamatergic transmission in substantia gelatinosa neurons. J Neuroinflammation 2014;11:7.

20 Grimsey NL, Goodfellow CE, Scotter EL, Dowie MJ, Glass M, Graham ES: Specific detection of CB 1 receptors; cannabinoid CB 1 receptor antibodies are not all created equal! J Neurosci Methods 2008;171:78-86.

21 Ashton JC: The use of knockout mice to test the specificity of antibodies for cannabinoid receptors. Hippocampus 2012;22:643-644.

22 Zoppi S, Pérez Nievas BG, Madrigal JL, Manzanares J, Leza JC, García-Bueno B: Regulatory role of cannabinoid receptor 1 in stress-induced excitotoxicity and neuroinflammation. Neuropsychopharmacology 2011;36:805-818.

23 Gustafsson SB, Palmqvist R, Henriksson ML, Dahlin AM, Edin S, Jacobsson SO, Öberg Å, Fowler CJ: High tumour cannabinoid CB1 receptor immunoreactivity negatively impacts disease-specific survival in stage II microsatellite stable colorectal cancer. PLoS One 2011;6:e23003.

24 Chung SC, Hammarsten P, Josefsson A, Stattin P, Granfors T, Egevad L, Mancini G, Lutz B, Bergh A, Fowler CJ: A high cannabinoid CB1 receptor immunoreactivity is associated with disease severity and outcome in prostate cancer. Eur J Cancer 2009;45:174-182. 


\section{Cellular Physiology Cell Physiol Biochem 2017;43:2516-2524

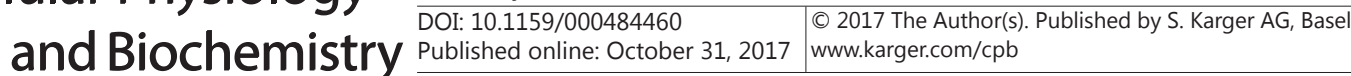 \\ Jing et al.: RIPC Attenuates BSCB Breakdown Following I/R Injury Mediated by CB1 and CB2 Receptors}

25 Burston JJ, Sagar DR, Shao P, Bai M, King E, Brailsford L, Turner JM, Hathway GJ, Bennett AJ, Walsh DA, Kendall DA, Lichtman A, Chapman V: Cannabinoid CB2 receptors regulate central sensitization and pain responses associated with osteoarthritis of the knee joint. PLoS One 2013;8:e80440.

26 Campora L, Miragliotta V, Ricci E, Cristino L, Di Marzo V, Albanese F, Federica Della Valle M, Abramo F: Cannabinoid receptor type 1 and 2 expression in the skin of healthy dogs and dogs with atopic dermatitis. Am J Vet Res 2012;73:988-995.

27 Ballabh P, Braun A, Nedergaard M: The blood-brain barrier: an overview: structure, regulation, and clinical implications. Neurobiol Dis 2004;16:1-13.

28 Vorbrodt AW: Molecular anatomy of intercellular junction in brain endothelial and epithelial barriers: electron microscopist's view. Brain Res Rev 2003;42:221-242.

29 Anttila V, Haapanen H, Yannopoulos F, Herajärvi J, Anttila T, Juvonen T: Review of remote ischemic preconditioning: from laboratory studies to clinical trials. Scand Cardiovasc J 2016;50:355-361

-30 Panikashvili D, Simeonidou C, Ben-Shabat S, Hanus L, Breuer A, Mechoulam R, Shohami E: An endogenous cannabinoid (2-AG) is neuroprotective after brain injury. Nature 2001;413:527-531.

-31 Arevalo-Martin A, Garcia-Ovejero D, Sierra-Palomares Y, Paniagua-Torija B, Gonzalez-Gil I, Ortega-Gutierrez S, Molina-Holgado E: Early Endogenous Activation of CB1 and CB2 Receptors after Spinal Cord Injury Is a Protective Response Involved in Spontaneous Recovery. PLoS One 2012;7:e49057.

32 Jin KL, Mao XO, Goldsmith PC, Greenberg DA: CB1 cannabinoid receptor induction in experimental stroke. Ann Neurol 2000;48:257-261.

-33 Ashton JC, Rahman RM, Nair SM, Sutherland BA, Glass M, Appleton I: Cerebral hypoxia-ischemia and middle cerebral artery occlusion induce expression of the cannabinoid CB2 receptor in the brain. Neurosci Lett 2007;412:114-117.

-34 Fernandez-Lopez D, Martinez-Orgado J, Nunez E, Romero J, Lorenzo P, Moro MA, Lizasoain I: Characterization of the neuroprotective effect of the cannabinoid agonist WIN-55212 in an in vitro model of hypoxic-ischemic brain damage in newborn rats. Pediatr Res 2006;60:169-173.

-35 Nunez E, Benito C, Pazos MR, Barbachano A, Fajardo O, Gonzalez S, Tolon RM, Romero J: Cannabinoid CB2 receptors are expressed by perivascular microglial cells in the human brain: an immunohistochemical study. Synapse 2004;53:208-213.

-36 Zhang M, Martin BR, Adler MW, Razdan RK, Ganea D, Tuma RF: Modulation of the balance between cannabinoid $\mathrm{CB}(1)$ and $\mathrm{CB}(2)$ receptor activation during cerebral ischemic/reperfusion injury. Neuroscience 2008;152:753-760.

37 Gong JP, Onaivi ES, Ishiguro H, Liu QR, Tagliaferro PA, Brusco A, Uhl GR: Cannabinoid CB2 receptors: immunohistochemical localization in rat brain. Brain Res 2006;1071:10-23.

38 Garcia-Ovejero D, Arevalo-Martin A, Petrosino S, Docagne F, Hagen C, Bisogno T, Watanabe M, Guaza C, Di Marzo V, Molina-Holgado E: The endocannabinoid system is modulated in response to spinal cord injury in rats. Neurobiol Dis 2009;33:57-71. 